\title{
Merja Leppälahti
}

University of Turku, Finland

meleppa@utu.fi

\section{Cultural Heritage in Picturebooks: Mauri Kunnas's Doghill and The Canine Kalevala}

Izvorni znanstveni rad / original research paper

Primljeno / received 24. 2. 2014. Prihvaćeno / accepted 10. 7. 2015.

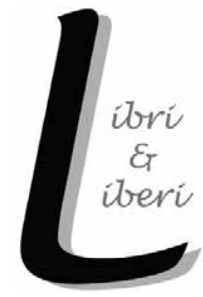

Some of Mauri Kunnas's picturebooks are examined as bearers of Finnish cultural heritage. His Doghill series conveys heritage by describing country life in $19^{\text {th }}$-century western Finland. Kunnas's The Canine Kalevala is an adaptation of the Finnish epic The Kalevala and also includes several adaptations of Akseli Gallen-Kallela's Kalevala paintings. Both The Kalevala and the paintings of Gallen-Kallela, held in high esteem in Finland, are adapted for child readers by Kunnas, who retells the story by using animal characters, omits problematic issues and adds humour to make it more appropriate for children. An informed adult reader reads The Canine Kalevala as an adaptation of The Kalevala, with an understanding of complex cultural and literary references, while a child reader sees the book as a new, exciting story.

Keywords: adaptation, Doghill series, Akseli Gallen-Kallela, heritage, Kalevala, Mauri Kunnas, picturebooks

In this paper some of the picturebooks written by Finnish author Mauri Kunnas are analysed as bearers of cultural heritage. The term heritage or cultural heritage is nowadays used very often, but seems quite difficult to define (Harvey 2007: 25, 37). There are almost as many definitions as there are heritage commentators. In the simplest of terms, heritage is what contemporary society chooses to inherit and pass on; it is something that has been defined as worth saving. UNESCO has drawn up a list of World Heritage Sites, but heritage can also be defined within a country, community or smaller group (Hovi 2014: 24-25; see also Bendix 2000, Hall 2007). 
The paper first focuses on Kunnas's Koiramäki [Doghill] series. Relying on animal characters, this series of seven picturebooks describes the past in a manner similar to its presentation in museums, but more humorously and in a less complicated way. Secondly, the Koirien Kalevala [The Canine Kalevala], a picturebook adaptation of the Finnish national epic The Kalevala, is examined. Since the story of The Canine Kalevala comes from The Kalevala, it can be called a re-writing or hypertext of the said epic (cf. Genette 1997: 5). In addition to the text, some of the pictures in The Canine Kalevala are adaptations of the canonical Kalevala paintings by Akseli Gallen-Kallela ${ }^{1}$ (1865-1931). The Canine Kalevala is a picturebook, but it is often considered to be a book for both children and adults (Virtanen 2007: 72-73).

The importance of Kunnas's picturebooks as bearers of cultural heritage has already been recognised and studied by several authors, mostly in the context of translation studies: for instance, Melissa Garavini (2014) and Hanna-Maria Hyvönen (2004) study Italian translations of Kunnas's books, with special emphasis on translations and adaptations of culture-specific elements. Kunnas's Christmas books (cf. Hyvönen 2004, Tettinen 2014) and books from the Doghill series have so far received most scholarly attention: Elina Järvinen (2011), for instance, analyses personal names in the Doghill books, while Liisa Saarinen (2013) studies how the past is represented in one of the books from that series, Doghill Martha and Runeberg.

This study focuses on the way cultural and historical content is presented so as to be accessible to child readers, and how Kunnas uses pictures in the analysed picturebooks to mediate complex meanings and build an awareness of cultural identity. Cultural heritage is thus considered a component of a system of values, an ideology that is conveyed to children in the process of reading pictures in picturebooks by Kunnas. As John Stephens puts it (1992: 8):

Ideologies $[\ldots]$ are not necessarily undesirable, and in the sense of a system of beliefs by which we make sense of the world, social life would be impossible without them. If a child is to take part in society and act purposively within its structures, he or she will have to master the various signifying codes used by society to order itself.

\section{Mauri Kunnas and his works}

Before he began publishing picturebooks, Mauri Kunnas studied graphic design and drew comic strips and caricatures for newspapers. Today he is very well known in Finland and is one of the most popular Finnish authors of picturebooks.

\footnotetext{
1 He changed his name from Gallén to Gallen-Kallela in 1907.
} 
In all, Mauri Kunnas has already published over forty picturebooks and he keeps writing more. ${ }^{2}$ His books have also sold well both in Finland and abroad. So far, his books have been published in 34 countries and translated into 31 languages (Mauri Kunnas $^{3}$ ).

The first picturebook by Mauri Kunnas was Suomalainen tonttukirja (The Book of Finnish Elves), published in 1979. The book, illustrated by Kunnas himself, consists of folktales about house elves from the Finnish folklore archives. The last story, which tells of one elf's celebration of Christmas, is not a folktale but a story written specifically for the book. However, it contains many references to a traditional Finnish Christmas: the elf, for instance, particularly likes the tradition of leaving the Christmas feast on the table overnight for the house elf to eat. The book has been very well received and is still in print.

Internationally, Joulupukki [Santa Claus] is Kunnas's best-known and bestselling book; it has been translated into 26 languages. In Finnish folklore, the character of Santa Claus is not nearly as old as, for example, the house elves. Christmas elves helping Santa Claus are also a more recent tradition, but they have assumed many characteristics of traditional Finnish house elves, like the red pointy hats. Kunnas makes use of this in his book, explaining that Santa's elves are former house and forest elves that have moved to the peaceful Lapland from cities and industrialised areas. Nevertheless, Kunnas's Santa Claus does fit the contemporary Finnish idea of Santa very well.

In most of his books, Kunnas uses animal characters. He is especially known for the Koiramäki [Doghill] series, which uses characters of anthropomorphic dogs to describe life in the past. The three original Doghill books, published from 1980 to 1988, are discussed in more detail below. Another famous book is Koirien Kalevala [The Canine Kalevala] in which characters from The Kalevala are dogs, cats and wolves. Kunnas also uses dog characters in his book Seitsemän koiraveljestä [The Seven Dog Brothers], which is an adaptation of Aleksis Kivi's 1870 novel Seitsemän veljestä [Seven Brothers].

Kunnas has used animal characters in many of his other works, such as books about the Vikings, vampires, pirates, King Arthur and Robin Hood. One of his most popular characters is Herra Hakkarainen (Mr. Clutterbuck), a sleepwalking goat who unwittingly performs heroic deeds. He first appeared in Hyvää yötä, herra Hakkarainen [Good Night, Mr. Clutterbuck] (1999). Many new books by Kunnas have a "hidden" picture of the sleepwalking Mr. Clutterbuck in them.

2 Mauri Kunnas's wife, Tarja Kunnas, has coloured many of the pictures for his books and has also taken part in designing the books. She is mentioned in some of the books as co-author.

3 Mauri Kunass's official web site $<$ http://maurikunnas.net/ $>$. 
The style of Kunnas's illustrations is reminiscent of the style of comic books and caricatures. Kunnas's animal characters usually have round white eyes as comicbook characters do and they are typically quite "rough" rather than cute (Virtanen 2007: 96). The books abound in movement, even though Kunnas makes very little use of speed lines, or motion lines, which are typical of comics (cf. McCloud 1994: 110-114). The impression of movement in Kunnas's illustrations is created mainly through the characters' positions in relation to each other (Happonen 2001: 101-103), presented as either transactional or bi-transactional processes (cf. Kress and van Leeuwen 2006: 64-66). One page, or even just one picture, can illustrate all the different stages of processes such as washing clothes or harvesting crops in the past, representing "continuous narrative" illustrations (cf. Schwarcz 1982: $23 \mathrm{ff}$ ). Many characters are busily working on different tasks, which creates the feeling of motion throughout the picture. For buildings, Kunnas often uses the socalled "open house" structure, also known in scholarly writings on children's books as the "doll house" structure (Ylimartimo 2001: 88-90). This provides a view of the entire interior of the building from the side or the top, allowing the viewer to see either many rooms at once, or the back and front of the same room within the same picture.

Kunnas has received awards ${ }^{4}$ and praise for popularising heritage among children: "Kunnas has brought Finnish folklore and history into nurseries and kindergartens" (Press release of Aalto University, 26 October 2012; Tjnk 2013) and making key works of Finnish literature (The Kalevala and Seven Brothers) appropriate for young readers and listeners (Tjnk 2013).

\section{The Doghill books as heritage bearers}

In Finland, books from the Doghill series are among Kunnas's most widely recognised work. The three original Doghill books are Koiramäen talossa [Doghill Farm] (1980), Koiramäen lapset kaupungissa [The Doghill Kids Go to Town] (1982), and Koiramäen talvi [Winter at Doghill Farm] (1982). Some later books by Kunnas also reveal connections with the Doghill series, e.g. Koiramäen lasten joulukirkko [Doghill Children in Christmas Church] (1997), ${ }_{5}^{5}$ Koiramäen Martta

${ }_{4}$ Among the many awards given to Mauri Kunnas is the State Award for Public Information (2013) for his distinguished life's work. He also received the title doctor honoris causa from Aalto University.

5 This book was created to raise funds for rebuilding the Saint Olaf Church in Tyrvää, which had burned down in 1997. Set in the past, the book tells about the Doghill children's visit to that same church. 
ja Tiernapojat [Doghill Martha and the Christmas Pageant] (2000), ${ }^{6}$ Koiramäen Martta ja Ruuneperi [Doghill Martha and Runeberg] (2005), ${ }^{7}$ and Koiramäen lapset ja näkki [Tales from Doghill] (2007), which includes several old Finnish folktales. $^{8}$

The first book in the series, Doghill Farm, appeared soon after The Book of Finnish Elves. Inhabitants of Doghill farm include the farmer, his wife and children, grandma, grandpa and the farmhands, all of them represented as anthropomorphised dogs wearing clothes, living in houses and doing human chores. Life on Doghill farm presents life in the countryside of western Finland in the $19^{\text {th }}$ century: baking bread, herding cows, shearing sheep, and weaving cloth.

Heritage is a part of culture or history, the preservation of which is considered to be especially important, e.g. in museums (Hall 2007: 87, Hovi 2014: 24-25). The Doghill house was inspired by buildings in the farmhouse museum in Satakunta, in western Finland, where Kunnas himself lived as a child. Kunnas's images of various tasks, tools and props are ethnologically accurate, and the items in the pictures are clearly labelled. Kunnas points out that he carefully checks such details and uses real museum items as references for his illustrations (Mauri Kunnas).

In the second Doghill book, The Doghill Kids Go to Town, two of the Doghill farm children, Elsa and Kille, visit their relatives in town. There they get to experience town life in the 1850s. Together with their relatives, Elsa and Kille go to the store, the pharmacy, the market square and the harbour. They also visit the homes of some of the townsfolk. They take wool for spinning to a small cottage at the edge of town, and wedding confections made at their relatives' bakery to a wealthy house. All this enables Kunnas to demonstrate how people lived in the 1850s. The pictures show scenes from historical Turku, a town in the south-west of Finland. The location is reflected in the names of places and characters: for instance, the names of the families the Doghill kids visit, Kinkeliin and Juliin, are vernacular forms of the family names Kingelin and Julin.

The third book in the Doghill series, Winter at Doghill Farm, tells about life in the $19^{\text {th }}$-century Finnish countryside during winter. The Doghill children

6 Tiernapojat (literally: "star-boys") is a group of four singers who sing the story of Christmas. In Finland, this tradition has been known from at least the $18^{\text {th }}$ century.

7 Johan Ludvig Runeberg (1804-1877) was a famous Fenno-Swedish poet.

8 In 2013, Koiramäen tarinat [Tales from Doghill] was published, a collection that brings together the first three as well as two other Doghill books in one volume. The two other Doghill books are Doghill Children in Christmas Church and Koiramäen lapset ja näkki (the English translation bears the name Tales from Doghill, but the literal translation is "The Doghill Children and näkki" [näkki is a mythical water-creature in Finnish folktales]). 
visit their friends who live in a "smoke-hut", a house with no chimney, and attend school which is organised in the village for a few weeks at a time (for more on representations of the past in children's literature, see Lucas 2003).

Children's books often feature child or animal characters, which seem to be closer to child readers. Perry Nodelman draws attention to the "similarity of children to animals" (2004: 159) and points out that "the state of animals who talk like humans is a metaphor for the state of human childhood" (161). John Stephens, on the other hand, argues that the anthropomorphism allows readers to both empathise with a dog character's human emotions, and be distanced from his dogginess (1992: 134). Both authors place anthropomorphic characters in the more general context of mediating cultural meanings and ideology (Nodelman 2004: 159-160):

Like most narrative, picture book stories most forcefully guide readers into culturally acceptable ideas about who they are through the privileging of the point of view from which they report on the events they describe [...] All stories imply subject positions for readers to occupy. [...] [P]icture books do so with pictures as well as words.

Stephens points out that "the discourses of children's fiction are pervaded by ideological presuppositions, sometimes obtrusively and sometimes invisibly" (1992: 1-2), and that (2-3):

in anthropomorphic picture books or folk tales in which animals are depicted performing social actions and functions particular to human beings, [...] the discrepancy between human and animal behaviour can easily mask the assumption that the implied human behaviour reflects social reality.

Kunnas frequently uses anthropomorphic animals for such purposes. Nearly every double-page spread in the book features the Doghill children doing something related to the tasks the adults are doing, or playing near the working adults. This shows life in the past from a child's perspective and makes the pictures more interesting for child readers. Stephens explains (1992: 3):

Writing for children is usually purposeful, its intention being to foster in the child reader a positive apperception of some socio-cultural values, which, it is assumed, are shared by author and audience. These values include contemporary morality and ethics, a sense of what is valuable in the culture's past (what a particular contemporary social formation regards as the culture's centrally important traditions), and aspirations about the present and future.

Kunnas thus employs the representation of characters to convey cultural and traditional information and values and makes them more easily understandable for child audiences through anthropomorphic animals. 
Rather than rely on a specific plot to organise the narrative, the Doghill books are structured around pictures. ${ }^{9}$ Paula Havaste notes that the function of the text in the Doghill books is to tie together the central themes of the pictures (2001: 138-139). Each spread features an event or an activity illustrated with one or more pictures and accompanied by a relatively small amount of text. As Stephens puts it, visual representations "encourage a more complex response to the text. Pictures can reveal things that the words do not" (1992: 163). Picturebooks combine words and pictures to produce complex meanings, and they have "a capacity to construct and exploit a contradiction between text and picture so that the two complement one another and together produce a story and a significance" (164). In other words, they "communicate only within a network of conventions and assumptions, about visual and verbal representations and about the real objects they represent" (Nodelman 2004: 157).

Kunnas thus uses pictures and words to engage young readers and raise their awareness of tradition and culture on which they can build their individual identities. He employs the form of picturebook to convey complex ideological content and cultural meanings to children, who are generally an inexperienced audience, and, as such, "in need of learning how to think about their world, how to see and understand themselves and others. Consequently, picturebooks are a significant means by which we integrate young children into the ideology of our culture" (Nodelman 2004: 157).

The Doghill series is considered to teach accurate lessons about the past, in a way that appeals to children. When visiting a museum, children enjoy seeing the same objects they have already seen in the Doghill books. When families visit museums, children can sometimes name obsolete farm tools and objects from everyday life that even adults cannot recognise. Examples such as these show that Kunnas's picturebooks play an important part in preserving heritage and transmitting knowledge about heritage to young readers.

Not only are child readers of the Doghill books interested in visiting museums, but museums also use the Doghill series to attract families. Kunnas modelled the Doghill farm on buildings from the Yli-Kirra Farm Museum in Punkalaidun (Mauri Kunnas); nowadays, that museum is explicitly publicised as "The Doghill House". Many other museums offer special Doghill-themed exhibitions aimed at children, and the North Ostrobothnia Museum in Oulu even has a permanent "Doghill" section where life in the past is depicted by using Doghill-themed miniatures. The

9 The detailed illustrations in the Doghill books are evocative of picturebooks by Richard Scarry (1919-1994), a popular American author and illustrator of children's books. Kunnas himself has mentioned Scarry as one of his sources of inspiration (Mauri Kunnas). 
Doghill theme is also used in other places besides museums to attract families with children. A Doghill theme park was opened in Tampere in the summer of 2013, while the city of Turku offers visitors a "Doghill Kids' Town Tour", which includes sites depicted in the book The Doghill Kids Go to Town. ${ }^{10}$

Presenting the past to non-academic audiences, especially young children, is sometimes seen as problematic. Often only cultural heritage that is considered interesting and acceptable ends up being portrayed, with any difficult or unpleasant topics omitted. The past is depicted in a nostalgic and romanticised way (Bendix 1997: 188-199, Lumley 2005: 15-25). In his books, Kunnas also shows life in the past as uncomplicated and blissful. Most of the characters are shown smiling or laughing. Poverty, hunger or sickness is not depicted. The fact that timber worker Hunsteen's entire large family lives in a single small room (in The Doghill Kids Go to Town) or that Karvaturri's children who reside in a smoke-filled hut have only one pair of shoes they all share (in Winter at Doghill Farm) is presented merely as a curiosity. These families are also presented as happy and smiling. However, the Doghill series has not been criticised for depicting historical times and circumstances as nice and unproblematic.

\section{Dogs and the national epic}

In addition to the Doghill series, Mauri Kunnas is also well known for his adaptation of the Finnish national epic The Kalevala into Koirien Kalevala, which was published in 1992. ${ }^{11}$ This book has been translated into English [The Canine Kalevala (1992)], Swedish [Hundarnas Kalevala (1994)], and Karelian [Koirien Kalevala vienankarjalaksi (2010)]. In this book, once again all the characters are animals: dogs, wolves and cats.

The Finnish national epic The Kalevala was compiled from Karelian and Finnish oral folklore verses by Elias Lönnrot and published in 1835. After that, Lönnrot gathered so much more folklore material that he expanded The Kalevala considerably and changed the order of some of its parts. The new Kalevala was published in 1849. What is known as The Kalevala today is the new version, while the older version from 1835 is known as "the old Kalevala". Later, in 1862, Lönnrot made an abridged version of The Kalevala for schools (cf. Honko 2002, Kaukonen 1979).

\footnotetext{
${ }^{10}$ Some of Kunnas's other books have also been used for the purposes of family tourism. The sleepwalking goat Mr. Clutterbuck is so popular that Kunnas's home town Sastamala has a tourist attraction called "Herra Hakkaraisen talo" (Mr. Clutterbuck's House).

${ }^{11}$ This book has become quite popular among both children and adults in Finland. It has been adapted into many children's theatre productions and there is even an opera version of the book.
} 
Many artists have been inspired by the epic. One of them was Akseli GallenKallela (1865-1931), whose powerful paintings have acquired a canonical status among illustrations of The Kalevala (Itkonen 2009: 123). Among the most famous of Gallen-Kallela's Kalevala paintings are Aino-triptyykki [The Aino Triptych] (1891), Sammon taonta [The Forging of the Sampo] (1893), Sammon puolustus [The Defence of the Sampo] (1896), Joukahaisen kosto [The Retribution of Joukahainen] (1897), Lemminkäisen äiti [The Mother of Lemminkäinen] (1897), Kullervon sotaanlähtö [Kullervo's Departure for War] (1901), Sammon ryöstö [The Raid for the Sampo] (1905), and Ilmarinen kyntää kyisen pellon [Ilmarinen Ploughs a Field Full of Adders] (1928). Adaptations of all Gallen-Kallela's paintings mentioned above can be seen in The Canine Kalevala, where they are always labelled in the margins as "a doggy adaptation of Akseli Gallen-Kallela's [the name of the painting]."

Many of Gallen-Kallela's Kalevala paintings are widely known in Finland: they are featured in schoolbooks, magazines, on covers of books and records, on posters and in advertisements (Itkonen 2009: 123). ${ }^{12}$ Adult Finnish readers have probably seen many versions of Gallen-Kallela's Kalevala paintings or perhaps even the originals themselves. To younger readers, the Gallen-Kallela adaptations in The Canine Kalevala can simply be pictures like all others, unless the adult reader draws their attention to them. Since the adaptations of Gallen-Kallela's paintings in The Canine Kalevala are labelled, literate young readers might also notice that some pictures are somehow specific.

The last thirty years have seen a resurgence of interest in The Kalevala. Numerous books with intertextual links to The Kalevala were published in Finland; some of them are new versions of The Kalevala, others have less obvious connections. Mauri Kunnas's The Canine Kalevala was among the first books that marked this new wave of interest in the epic (Leppälahti 2012: 63-83).

After The Canine Kalevala was published, many literary critics praised Kunnas's attempts to present Finnish cultural heritage to children, but some were confused: what to make of dogs in the highly distinguished Kalevala epic and Gallen-Kallela's paintings? (Virtanen 2007: 48-65). The Canine Kalevala is a picturebook, but it is often considered to be a book for both adults and children, as it can provide intellectual, aesthetic and even emotional pleasure to an adult reader (cf. Arizpe and Styles 2004: 21). The crossover readership of adults and children is often recognised as a common feature of all (quality) picturebooks. As Sandra Beckett has shown, "picturebooks offer a unique opportunity for a collaborative

${ }^{12}$ A Donald Duck version of Gallen-Kallela's Sammon puolustus [The Defence of the Sampo] was used as the cover picture for Don Rosa's 1999 comic book Sammon salaisuus [The Secret of the Sampo]. 
or shared reading experience between children and adults, since they empower the two audiences more equally than other narrative forms" (2012: 2), so that "many crossover picturebooks offer challenging reading experiences for adults as well as children" (3).

\section{The original epic and The Canine Kalevala}

The Kalevala starts with the creation of the world. Ilmatar, the virgin spirit of the air, floats on the surface of the ocean. A bird lays an egg on her knee and the world is created from parts of the egg. The main character of The Kalevala is Väinämöinen, born as a fully grown man after Ilmatar's thirty-year-long pregnancy. Other male heroes of The Kalevala are Ilmarinen, Lemminkäinen, Joukahainen, and Kullervo. The most important female characters are Louhi, who forces Ilmarinen to forge the Sampo, ${ }^{13}$ Aino, Kyllikki, Marjatta, and Lemminkäinen's nameless mother.

The plot of The Canine Kalevala follows the storyline of The Kalevala, but the creation of the world and the birth of Väinämöinen are left out. In some places, verses from The Kalevala have been almost directly "translated" into comprehensible prose for children. ${ }^{14}$ The narrative starts in the Kalevala village, inhabited by the wild and free dog tribe and their famous hero Väinämöinen. The neighbouring village of Pohjola is home to a fierce and mean tribe of wolves. Somewhere between these two villages lives a small tribe of cats.

\section{Adapting the story of Aino}

The adaptation of the story of Aino reveals the most notable differences between The Canine Kalevala and The Kalevala. In The Kalevala, Joukahainen challenges Väinämöinen to a spell-singing contest, and Väinämöinen's spell makes Joukahainen sink into a marsh. To get out, Joukahainen promises Väinämöinen his sister Aino. Väinämöinen is thrilled, but Aino refuses to marry an old man. Väinämöinen and Aino accidentally meet in the forest: Väinämöinen is very pleased, but Aino is shocked and later drowns in the sea.

In The Canine Kalevala, Väinämöinen and Joukahainen also compete against each other, and Joukahainen has to promise Väinämöinen his sister. Joukahainen, Aino, and their mother start planning the wedding, but Väinämöinen believes

\footnotetext{
${ }^{13}$ The Sampo is said to be a magic mill that can grind many kinds of goods. In addition to the mill, researchers have interpreted the Sampo as the sun, the moon, the North Star, a rainbow, a cloud, a temple, the image of a god, a dragon ship, a musical instrument, a shield, a shaman drum, a box, and some kind of charm or amulet (Harva 1943: 16-17).

${ }^{14}$ The original language of The Kalevala can be quite difficult to understand even for a native Finnish speaker, because it is an archaic eastern dialect.
} 
that Aino will become his maid servant. Aino, however, really wants to marry the famous and powerful hero. Väinämöinen and Aino accidentally meet in the forest: Väinämöinen is shocked when Aino tells him they will soon get married. Later, Aino tries to catch Väinämöinen while he is swimming. ${ }^{15}$

One of Gallen-Kallela's famous Kalevala paintings is the Aino Triptych, ${ }^{16}$ which consists of three paintings of the story of Aino. The picture on the left illustrates the meeting between Väinämöinen and Aino in the forest. The middle painting depicts the naked Aino who is in the water, trying to escape Väinämöinen, who is in a boat. The painting on the right shows the naked Aino stepping into the water, where water spirits are waiting for her.

The Canine Kalevala includes adaptations of only two parts of the Triptych: the left and the middle one. In the central picture, Väinämöinen is in the water and Aino is trying to catch him from the boat. The picture resembles Gallen-Kallela's painting, but the characters have been reversed. As mentioned above, events described in the text of The Canine Kalevala also differ from those featured in The Kalevala.

The character of Aino has been the subject of critical re-evaluation. Some previous male researchers admire Aino's "humble passive femininity" (Tarkiainen 1911: 33), but many modern female researchers see her as a strong woman who is not afraid to make decisions about her own destiny (Piela 1999: 126). Re-evaluation can also be detected in Kunnas's interpretation of the character, seen in the novel use of the middle painting of Gallen-Kallela's Aino Triptych (cf. Kailo 2000: 27). The reviews of The Canine Kalevala also noticed the modern presentation of the story of Aino (Virtanen 2007: 65-66).

The adaptation of Gallen-Kallela's Joukahaisen kosto [Joukahainen's Revenge] in The Canine Kalevala shows Joukahainen who is getting ready to shoot Väinämöinen with his arrow. As in Gallen-Kallela's painting, his mother is standing behind him, but unlike the painting, the illustration in The Canine Kalevala also depicts Aino. In The Kalevala, Joukahainen wants revenge for the outcome of the spell-singing contest. His mother asks Joukahainen not to shoot, because without Väinämöinen there would be no joy or singing in the world any more. In The Canine Kalevala, the whole family is angry because Väinämöinen did not marry Aino. Both the mother and Aino urge Joukahainen to shoot. Joukahainen shoots, and Väinämöinen falls into the water, as he does in The Kalevala ${ }^{17}$

\footnotetext{
${ }^{15}$ As in The Kalevala, in Kunnas's book Väinämöinen and Aino do not get married.

${ }^{16}$ Actually there are two versions of the Aino Triptych: one from 1889 and the other from 1891 . The picture in The Canine Kalevala is an adaptation of the 1891 painting.

${ }^{17}$ In both The Kalevala and The Canine Kalevala, Väinämöinen is saved and brought to Pohjola. This is the beginning of the story of the Sampo.
} 


\section{An epic for children}

Literary adaptations can be motivated by a wish to present something complex and considered valuable (like Shakespeare's plays or The Kalevala) to broader or entirely new audiences. To make them more appealing to new readers, existing texts are often presented in a more comprehensible way and, in the case of adaptations for children, made less violent and more optimistic (Hutcheon 2006: 91-92, 114; see also Müller 2014).

The Canine Kalevala follows the central storyline of The Kalevala, but some episodes have been modified, while "delicate" details have been left out altogether. When he visits the village of Pohjola, Lemminkäinen does not kill its master (or anyone else, for that matter) by cutting off his head, as he does in The Kalevala, but rather causes a fight by pushing the wolves of Pohjola off a rock on which they stand singing. Later, instead of being cut into pieces on the River Tuonela, he falls into the river. In search of her son, Lemminkäinen's mother combs the river with a rake. First she finds his socks and helmet. After finding Lemminkäinen, the mother manages to revive him by rolling his body with a piece of wood, which is shown in the picture. In The Canine Kalevala, the character of Lemminkäinen is a cat, and the text mentions that cats have nine lives.

Some central figures of The Kalevala have been completely left out of The Canine Kalevala. Most notable of these omitted characters are Kyllikki, Kullervo and Marjatta. They are all connected to events and themes that might be difficult to explain to a small child, such as suicide and incest.

Kyllikki is a beautiful maiden whom Lemminkäinen seizes for his wife after seducing all the other women in her home village. Kyllikki refuses his advances, so he takes her away by force, but soon abandons her and sets off to woo the Maiden of Pohjola.

Kullervo becomes an orphan because of a feud between his father and his uncle, the father's brother. His uncle repeatedly tries to kill little Kullervo by hanging or burning him, but does not succeed. When Kullervo grows up, he is sold as a slave to a blacksmith. The wife of the smith bakes a stone in the bread she gives him, and Kullervo sends the forest beasts to kill her. Later, Kullervo unknowingly seduces his own sister and ends up committing suicide. Although the character of Kullervo has been left out of The Canine Kalevala, an adaptation of Gallen-Kallela's painting Kullervon sotaanlähtö [Kullervo's Departure for War ${ }^{18}$ is included. However, the picture substitutes Kullervo with Lemminkäinen. A notable difference between Gallen-Kallela's painting and The Canine Kalevala (in addition to the change of

\footnotetext{
${ }_{18}$ After this 1901 painting, Gallen-Kallela also painted a fresco and a tempera painting of Kullervo's
} departure for war. The 1901 version was also used on a stamp in 1935. 
characters) is the addition of Lemminkäinen's mother who is trying to stop her son from leaving by hanging onto his horse's tail.

Marjatta is a folktale version of the story about the Virgin Mary. Marjatta becomes pregnant from eating a lingonberry and her parents drive her away from home. Marjatta gives birth to a boy in the forest and needs someone to give him a name. Väinämöinen comes along and instead of naming the child orders that he be killed. Although he is only three nights old, the child speaks out and accuses Väinämöinen of the foul deeds he had committed in his youth. After that, Väinämöinen leaves the village of Kalevala. ${ }^{19}$

The characters and events mentioned above have probably been left out of The Canine Kalevala because they might be difficult for children to understand. It might be frightening for a child to think about Kullervo's own uncle trying to kill him, about parents abandoning their children, or Väinämöinen sentencing a baby to death. Also, both incest and suicide are generally considered to be taboos in children's literature (cf. Beckett 2012: 265ff). These events might also have been difficult to square with the humorous tone of The Canine Kalevala. Leaving out the most problematic themes and issues dealt with in The Kalevala, The Canine Kalevala ensures that children, as the book's intended readers, are not exposed to topics such as sexuality and death, which might be considered inappropriate for them. When death does appear, as in the previously described example of Lemminkäinen's death, it is placed in the context of animal life. As Sandra Beckett points out, "[u]sing animal rather than human protagonists can make the subject less painful" (2012: 257), and here it also gets a humorous aspect.

For young readers, pictures in picturebooks are as important as text. They "provide an equality of access to narratives and ideas that would otherwise be denied to young readers" (Arizpe and Styles 2004: 223). The style of all the pictures in The Canine Kalevala is the same throughout, and noticing the Gallen-Kallela adaptations is not essential for understanding the story. As in the Doghill series, the pictures in The Canine Kalevala are very rich in amusing details. The child reader can be delighted by finding mice in funny places, such as inside Lemminkäinen's birch bark horn or by little hats on the heads of adders. Humorous pictures also alleviate the more sombre episodes described in the text.

Both in The Kalevala and The Canine Kalevala, the Sampo breaks and its pieces are scattered all over the sea. However, in The Canine Kalevala, small pieces are left floating on the water and waves bring some of them to the shore at the Kalevala village. Ilmarinen forges the pieces into small plaques which are attached

${ }^{19}$ Elias Lönnrot placed this story as the last one in The Kalevala to show that the old era has come to an end and a new one begins: Christianity takes the place of old beliefs and gods (Järvinen 1999: 146). 
to leather straps and given to the villagers to wear around their necks. Väinämöinen hopes that the pieces still have enough magic left in them to give every villager a pleasant life, a juicy bone in his cup and a soft mattress to lie on - and that is exactly what happens. The last picture in The Canine Kalevala shows a dog lying on a pillow, a collar around his neck and a ribbon around his tail. The ending of the book points out that The Canine Kalevala is, after all, a story about dogs.

\section{Concluding remarks}

Analyses of several picturebooks by Mauri Kunnas have shown that they function as bearers of cultural heritage. The Doghill series conveys Finnish heritage by describing $19^{\text {th }}$-century rural life in western Finland and establishes links with the way this period is presented in museums, i.e. as valuable and worth preserving in the cultural memory of young generations. The Canine Kalevala is an adaptation of the Finnish epic The Kalevala, and also includes several adaptations of Akseli Gallen-Kallela's Kalevala paintings. Both The Kalevala and the paintings by Gallen-Kallela are held in high regard in Finland.

In picturebooks, the story depends on the interaction between text and image: as an art form it is "based on the combination of two levels of communication, the visual and the verbal" (Nikolajeva and Scott 2001: 1). A good picturebook, as a whole, is more than the sum of its parts: "a whole is different from the component parts, but without those parts ever actually blending into one" (Nodelman 1988: 21). In the Doghill books, the pictures are clearly more important than the text. Unfamiliar ethnographic items and activities are easier to explain through images than words. In addition, many items in the Doghill books are labelled. The Doghill series teaches its child readers history, and children become interested in the past after reading these books. Museums use the series to attract families as visitors. The Canine Kalevala also includes ethnographic material. For instance, the presentation of skis is based on ethnographic knowledge, so when Lemminkäinen is shown skiing and wearing a pair of skis in a picture, one ski is short, and one is long, as it was in the past.

Adaptation involves both memory and change (Hutcheon 2006: 173). Adopting a new approach to an old story, The Canine Kalevala brings together The Kalevala (along with its canonical interpretations such as Gallen-Kallela's paintings) and animal characters. However, this is an adult interpretation. Children are not expected to spontaneously read all cultural signs even if those signs are familiar to their parents. The cultural asymmetry between children and adults makes them comparable to two different communities with different languages and cultural backgrounds (Franco Aixelá 1996: 53-54, Oittinen 2005). When reading 
about Finnish heritage, a Finnish child may occupy a position similar to that of a non-Finnish adult reader (Virtanen 2007: 96). This can be seen when reading the Doghill series with its ethnographical and historical details, but even more so in The Canine Kalevala which, in addition to the text of The Kalevala and pictures of Gallen-Kallela, contains cultural images and shows reverence for The Kalevala.

While Finnish adults usually know at least something about The Kalevala, for children the story told in The Canine Kalevala is new and they do not know what to expect. Unlike in the Doghill series, text plays an important role in The Canine Kalevala. In spite of that, research done by Tarja Virtanen reveals that young children reading The Canine Kalevala usually read the pictures without text, or, rather, they use the pictures as the basis for understanding the text (Virtanen 2007: 96). Rich and humorous pictures alleviate some of the themes addressed in the text. While adult readers recognise the Gallen-Kallela adaptations in The Canine Kalevala, children probably view them just as pictures. Although The Canine Kalevala is indeed a book for both adults and children, the two groups read the book in different ways. Adults read The Canine Kalevala through The Kalevala and Gallen-Kallela, while children see it is as a new story with humorous pictures. However, when encountering the original Kalevala in later years, they may be able to relate the story they remember from their childhood with ancient Finnish cultural and literary traditions, and discover new meanings.

\section{References}

Primary sources

Kivi, Aleksis. 1985 (1870). Seitsemän veljestä. Helsinki: Suomalaisen Kirjallisuuden Seura. Kunnas, Mauri. 1979. Suomalainen tonttukirja. Helsinki: Otava.

Kunnas, Mauri. 1980. Koiramäen talossa. Helsinki: Otava.

Kunnas, Mauri. 1981. Joulupukki. Helsinki: Otava.

Kunnas, Mauri. 1982. Koiramäen lapset kaupungissa. Helsinki: Otava.

Kunnas, Mauri. 1988. Koiramäen talvi. Helsinki: Otava.

Kunnas, Mauri. 1992a. Koirien Kalevala. Helsinki: Otava.

Kunnas, Mauri. 1992b. The Canine Kalevala. Translated by Tim Steffa. Helsinki: Otava. Kunnas, Mauri. 1994. Hundarnas Kalevala. Translated by Lars Huldén. Helsinki: Otava. Kunnas, Mauri. 1997. Koiramäen lasten joulukirkko. Helsinki: Otava.

Kunnas, Mauri. 1999. Hyvää yötä, herra Hakkarainen. Helsinki: Otava.

Kunnas, Mauri. 2000. Koiramäen Martta ja Tiernapojat. Helsinki: Otava.

Kunnas, Mauri. 2002. Seitsemän koiraveljestä. Helsinki: Otava.

Kunnas, Mauri. 2005. Koiramäen Martta ja Ruuneperi. Helsinki: Otava.

Kunnas, Mauri. 2007. Koiramäen lapset ja näkki. Helsinki: Otava.

Kunnas, Mauri. 2010. Koirien Kalevala vienankarjalaksi. Translated by Nadja Lutohina. Helsinki: Otava. 
Kunnas, Mauri. 2013. Koiramäen tarinat (Koiramäen talossa, Koiramäen lapset kaupungissa, Koiramäen talvi, Koiramäen joulukirkko, Koiramäen lapset ja näkki). Helsinki: Otava.

Lönnrot, Elias. 1849. Kalevala. Available from <www.finlit.fi/kalevala $>$ (accessed March 04, 2015).

\section{Secondary sources}

Arizpe, Evelyn and Morag Styles. 2004. Children Reading Pictures. Interpreting Visual Texts. London and New York: RoutledgeFalmer, Taylor \& Francis Group.

Beckett, Sandra. 2012. Crossover Picturebooks: A Genre for All Ages. New York and London: Routledge.

Bendix, Regina. 1997. In Search of Authenticity: The Formation of Folklore Studies. Madison: University of Wisconsin Press.

Bendix, Regina. 2000. "Heredity, Hybridity and Heritage." In Folklore, Heritage Politics and Diversity, edited by Pertti J. Anttonen, in collaboration with Anna-Leena Siikala, Stein R. Mathisen and Leif Magnusson, 38-54. Botkyrka: Multicultural Centre.

Franco Aixelá, Javier. 1996. "Culture-Specific Items in Translation.” In Translation, Power, Subversion, edited by Román Alvarez and M. Carmen-África Vidal, 52-78. Clevedon: Multilingual Matters.

Garavini, Melissa. 2014. La traduzione della letteratura per l'infanzia del finlandese all'italiano: l'esempio degli albi illustrati di Mauri Kunnas. Turku: University of Turku, 2014. Available from < http://www.doria.fi/handle/10024/96476 > (accessed May 25, 2015).

Genette, Gérard. 1997. Palimpsests. Literature in the Second Degree. Lincoln: University of Nebraska Press.

Hall, Stuart. 2007. "Whose Heritage? Un-settling 'The Heritage', Re-imagining the Postnation." In Cultural Heritage: Critical Concepts in Media and Cultural Studies, vol. 2, edited by Laurajane Smith, 87-100. London: Routledge.

Happonen, Sirke. 2001. "Liike, kuvakirja ja kuvitettu teksti." In Tutkiva katse kuvakirjaan, edited by Kaisu Rättyä \& Raija Raussi, 101-131. Helsinki: BTJ Kirjastopalvelu.

Harva, Uno. 1943. Sammon ryöstö. Helsinki: WSOY.

Harvey, David C. 2007. "Heritage Pasts and Heritage Presents: Temporality, Meaning and the Scope of Heritage Studies." In Cultural Heritage: Critical Concepts in Media and Cultural Studies, vol. 1, edited by Laurajane Smith, 25-44. London: Routledge.

Havaste, Paula. 2001. "Mauri Kunnas." In Kotimaisia lasten- ja nuortenkirjailijoita 3, edited by Ismo Loivamaa, 136-141. Helsinki: BTJ Kirjastopalvelu.

Honko, Lauri, ed. 2002. The Kalevala and the World's Traditional Epics. Helsinki: Finnish Literature Society.

Hovi, Tuomas. 2014. Heritage through Fiction. Dracula Tourism in Romania. Turku: University of Turku.

Hutcheon, Linda. 2006. A Theory of Adaptation. New York and London: Routledge, Taylor $\&$ Francis Group.

Hyvönen, Hanna-Maria. 2004. La traduzione dei culture-bound nei testi di ambientazione natalizia di Mauri Kunnas. Turku: University of Turku.

Itkonen, Satu. 2009. "Kansallisten ikonien kommentteja." In Kalevala kuvissa, edited by Riitta Ojanperä, 123-139. Helsinki: Valtion taidemuseo.

Järvinen, Irma-Riitta. 1999. "Marjatta.” In Kalevalan hyvät ja hävyttömät, edited by Ulla Piela, Seppo Knuuttila \& Tarja Kupiainen, 146-147. Helsinki: Suomalaisen Kirjallisuuden Seura. 
Järvinen, Elina. 2011. Henkilönnimet Mauri Kunnaksen Koiramäki-kirjoissa. Turku: University of Turku.

Kailo, Kaarina. 2000. "Monoculture, Gender and Nationalism: The Kalevala as a Tool of Acculturation." In Ethical Challenges for Teacher Education and Teaching: Special Focus on Gender and Multicultural Issues, edited by Vappu Sunnari \& Rauni Räsänen, 13-37. Oulu: Oulu University Press.

Kaukonen, Väinö. 1979. Lönnrot ja Kalevala. Helsinki: Suomalaisen Kirjallisuuden Seura.

Kress, Gunther and Theo van Leeuwen. 2006. Reading Images: The Grammar of Visual Design. London: Routledge.

Leppälahti, Merja. 2012. "Le Kalevala dans la littérature finlandaide contemporaine." In Le Fantastique et la science-fiction en Finlande et en Estonie, edited by Martin Carayol, 63-83. Paris: L'Harmattan.

Lucas, Ann Lawson, ed. 2003. The Presence of the Past in Children's Literature. Westport, CT: Praeger.

Lumley, Robert. 2005. "The Debate on Heritage Reviewed.” In Heritage, Museums and Galleries, edited by Gerard Corsane, 15-25. London: Routledge.

Mauri Kunnas. <http://maurikunnas.net/> (accessed March 04, 2015).

McCloud, Scott. 1994. Understanding Comics: The Invisible Art. New York: HarperPerennial.

Müller, Anja. 2014. Adapting Canonical Texts in Children's Literature. London, New Delhi, New York, Sydney: Bloomsbury.

Nikolajeva, Maria and Carole Scott. 2001. How Picturebooks Work. London and New York: Garland.

Nodelman, Perry. 1988. Words about Pictures: The Narrative Art of Children's Picture Books. Athens, Georgia: University of Georgia Press.

Nodelman, Perry. 2004. "Picture Books and Illustration." In International Companion Encyclopedia of Children's Literature, $2^{\text {nd }}$ edn., edited by Peter Hunt, 154-165. London and New York: Routledge.

Oittinen, Riitta. 2005. "Translating Culture.” Literatuur zonder leeftijd 19 (67): 45-56. Avaliable from < http://www.dbnl.org/tekst/_lit004200501_01/_lit004200501_01_00 22.php> (accessed May 25, 2015).

Piela, Ulla. 1999. “Aino-myytti.” In Kalevalan hyvät ja hävyttömät, edited by Ulla Piela, Seppo Knuuttila \& Tarja Kupiainen, 118-130. Helsinki: Finnish Literary Society.

Press release of Aalto University. $26^{\text {th }}$ October 2012. Available from $<$ http://design.aalto.fi/ fi/current/news/view/1e21f45e66875521f4511e289ebb32d053d5ecb5ecb/> (accessed May 25, 2015).

Rosa, Don. 1999. Sammon salaisuus ja muita Don Rosan parhaita [The Quest for Kalevala]. Translated by Jukka Lindfors. Helsinki: Helsinki Media.

Saarinen, Liisa. 2013. Adaptaatio kuvan ja sanan keinoin Mauri Kunnaksen teoksessa Koiramäen Martta ja Ruuneperi. Turku: University of Turku.

Schwarcz, Joseph H. 1982. Ways of the Illustrator: Visual Communication in Children's Literature. Chicago: American Library Association.

Stephens, John. 1992. Language and Ideology in Children's Fiction. London and New York: Longman.

Tarkiainen, Viljo. 1911. Aino ja muut Kalevalan naiset. Helsinki: WSOY.

Teittinen, Laura. 2014. Poistoja, korvauksiajaäänteellisiämukaelmia. Erisnimien kääntäminen suomesta saksaksi neljässä Mauri Kunnaksen jouluaiheisessa lastenkirjassa. Turku: University of Turku.

Tjnk. "The Reasoning of State Awards for Public Information 2013." Available from $<$ http:// www.tjnk.fi/fi/tsvfm > (accessed March 04, 2015). 
Virtanen, Tarja. 2007. Eläväksi haukuttu Kalevala. Mauri Kunnaksen Koirien Kalevalan aikuis-ja lapsilukijoiden vastaanotto. Master thesis. Tampere: University of Tampere.

Ylimartimo, Sisko. 2001. "Kanssa ja lisää, vaiko ohi ja jopa vastaan? Lastenkirjan kuvittaja myötä- ja mielikuvittelijana.” In Tutkiva katse kuvakirjaan, edited by Kaisu Rättyä \& Raija Raussi, 79-100. Helsinki: BTJ Kirjastopalvelu.

\section{Merja Leppälahti}

Sveučilište u Turkuu, Finska

Universität Turku, Finnland

\section{Kulturna baština u slikovnicama: Koiramäki i Koirien Kalevala Maurija Kunnasa}

U radu se neke od slikovnica svjetski poznatoga i istaknutoga finskoga autora Maurija Kunnasa analiziraju kao nositeljice finske kulturne baštine. Njegova serija slikovnica Koiramäki, u engleskome prijevodu Doghill [Pseće brdo], predstavlja baštinu opisujući seoski život na zapadu Finske u 19. stoljeću. Kunnasova slikovnica Koirien Kalevala, engleski The Canine Kalevala [Pseća Kalevala], adaptacija je finskoga epa Kalevala te uključuje i nekoliko adaptacija slika Akselija Gallen-Kallele nadahnutih Kalevalom. I ep i slike Gallen-Kallele u Finskoj su vrlo cijenjeni, a Kunnas ih prilagođava dječjim čitateljima posežući za životinjskim likovima, izbjegavajući problematične teme i dodajući humor u svoja prepričavanja. Upućeni odrasli čitatelj slikovnicu The Canine Kalevala čita kao adaptaciju Kalevale, s razumijevanjem složenih kulturnih i književnih referencija, dok dječji čitatelj u knjizi vidi novu i uzbudljivu priču.

Ključne riječi: adaptacija, Koiramäki, Akseli Gallen-Kallela, baština, Kalevala, Mauri Kunnas, slikovnica

\section{Kulturerbe in Bilderbüchern: Koiramäki und Koirien Kalevala von Mauri Kunnas}

Im Beitrag werden einige der Bilderbücher des weltbekannten finnischen Autors Mauri Kunnas als Träger des finnischen Kulturerbes untersucht. Seine Bilderbuchserie Koiramäki [dt. Hundeberg] stellt einen Beitrag zur Erhaltung des finnischen kulturellen Erbes dar, weil darin das Bauernleben im Norden Finnlands des 19. Jahrhunderts beschrieben wird. Das Bilderbuch von Kunnas unter dem Titel Koirien Kalevala [dt. Hundekalevala] ist eine Adaption des finnischen Kalevala-Epos und enthält einige Adaptionen der durch diesen Epos inspirierten Bilder von Akseli Gallen-Kallela. Sowohl der Epos als auch die Bilder von Gallen-Kallela werden in Finnland sehr geschätzt. Kunnas passt diese an die Fähigkeiten der junge Leser an, indem er in der Nacherzählung des Epos nach Tiergestalten greift, problematische Themen vermeidet und das Erzählte mit viel Humor ausstattet. Der schon versierte erwachsene Leser liest das Bilderbuch Koirien Kalevala als eine KalevalaAdaption mit Verständnis für die darin enthaltenen komplexen kulturellen und literarischen Bezüge, während der junge Leser im Buch eine neue und aufregende Geschichte entdeckt.

Schlüsselwörter: Adaption, Koiramäki, Akseli Gallen-Kallela, Kulturerbe, Kalevala, Mauri Kunnas, Bilderbuch 